\title{
Oleanolic acid from black raisins, Vitis vinifera with antioxidant and antiproliferative potentials on HCT 116 colon cancer cell line
}

\author{
Kandasamy Sasikumar ${ }^{1}$, Vinay Dubey ${ }^{1}$, Asit Ranjan Ghosh ${ }^{\circledR 1^{*}}$ \\ ${ }^{I}$ Department of Integrative Biology, School of Bio Sciences and Technology, VIT University, Vellore, Tamilnadu, India
}

\begin{abstract}
Vitis vinifera (black raisin) is commonly used in traditional medicine for the treatment of various ailments. In the present study, anti-oxidative and anti-cancer efficacy of oleanolic acid from ethyl acetate fraction of black raisins was evaluated and oleanolic acid was isolated without using of any chromatographic techniques and subjected to spectral assessment using UV-Vis spectrophotometer, ${ }^{1} \mathrm{H} \mathrm{NMR},{ }^{13} \mathrm{C}$ NMR, MS and FT-IR for structural confirmation. Antiproliferative efficacy of oleanolic acid against human colon adenocarcinoma HCT-116 cells was assessed using cell viability assay. The minimum inhibitory concentration $\left(\mathrm{IC}_{50}\right.$ ) was determined and found to be $40 \mu \mathrm{g} / \mathrm{mL}$ at $48 \mathrm{~h}$ incubation. Furthermore, antioxidant property of oleanolic acid was analyzed using DPPH method $\left(\mathrm{IC}_{50}\right.$ is $61.5 \mu \mathrm{g} / \mathrm{mL}$ ) by compared to standard antioxidants ascorbic acid, gallic acid, pyrogallol and butylated hydroxytoluene. Hence, the present study aims to establish the use of oleanolic acid as a potential therapeutic agent against human colon cancer.
\end{abstract}

Keywords: Vitis vinifera. Oleanolic acid. Anti-oxidant. Anti-proliferative.

\section{INTRODUCTION}

Black raisin (Vitis vinifera) belongs to the Vitaceae family. Many berries make up a cluster or bunch of grapes. Polyphenol is an important phytochemical in the grape which promotes many biological activities and has immense health-promoting benefits (Xia et al., 2010). Grapes are available in the form of fresh fruit, raisins, juice and wine. In India, $V$. vinifera has been used as a traditional medicine for human health over 2000 years ago in 'Darakchasava,' a well-known Indian herbal preparation. This 'Ayurvedic' medicine is prescribed as a cardiotonic (Prasad, Tyagi, 2015) and is also used in the prescriptions for cough, problems in the respiratory tract, catarrh, subacute cases of enlarged liver and spleen, as well as being used in alcohol-based tonics (Aasavs) (Wang, 2014).

The triterpenoids are natural compounds that are widely distributed in the skin and seeds of different edible fruits, such as olives and grapes (Allouche et al., 2009). Oleanolic acid (OA) is a major triterpenoid acid found in the fruits and is also present in both virgin olive oils and red wine (Pensec et al., 2016). The role of triterpenoids in the diet helps in the prevention of certain cancers, including

\footnotetext{
*Correspondence: A. R. Ghosh. Department of Integrative Biology, School of Bio Science and Technology (SBST), VIT University, Vellore -632014, Tamilnadu, India. E-mail: cidcvit@gmail.com
}

breast cancer (Patlolla, Rao, 2012). OA also has the potential to be used as an antifungal (Tang et al., 2000), anti-HIV (Khasiwada et al., 2000), diuretic (Alvarez, Maria, Saad, 2002), and anti-inflammatory effects (Singh et al., 1992). However there is little literature currently available with respect to their effects on colon carcinoma cells.

The present study was designed to isolate and purify $\mathrm{OA}$ in a limited resource laboratory and investigate its inhibitory effects on human colon carcinoma cell line HCT116 and also as an antioxidant potential.

\section{MATERIAL AND METHODS}

\section{General experiments}

UV-Vis Spectrophotometric analysis was run on a Shimadzu UV-2401 PC Spectrometer. FT-IR spectrum analysis was performed in $\mathrm{KBr}$ pellets on a Perkin Elmer FT-IR spectrum BX Spectrophotometer. A ${ }^{1} \mathrm{H}$ and ${ }^{13} \mathrm{C}$ NMR spectra were recorded on BrunkerAvance FT-NMR spectrometer operating at $300 \mathrm{MHz}$ and $100 \mathrm{MHz}$ respectively.

\section{Plant materials}

$V$. vinifera was sourced locally from the Vellore 
market. It was deseeded manually using a knife and the peel was dried in an oven at $50{ }^{\circ} \mathrm{C}$ for around $48 \mathrm{~h}$ and stored at $4{ }^{\circ} \mathrm{C}$.

\section{Extraction and isolation of oleanolic acid}

$20 \mathrm{~g}$ of black raisin ( $V$. vinifera) was taken and dried at $50^{\circ} \mathrm{C}$ for $48 \mathrm{~h}$, pulverized and extracted with $\mathrm{MeOH}$ under reflux $(6 \mathrm{~h})$. After removal of the solvent using a rotary evaporator, the thick paste of $\mathrm{MeOH}$ extract was obtained. The oleanolic acid was isolated from methanolic extract using modified solvent-solvent fractionation without using any sophisticated chromatographic techniques (Sasikumar, Ghosh, 2017; Shoba, Sasikumar, Sathiavelu, 2018). The methanol extract was then resuspended with Mili Q water and the aqueous insoluble extract was further washed with EtOAc. The washed soluble fraction of EtOAc was collected, dried and stored for further isolation process. The diethyl ether soluble fraction was separated from the EtOAc dried extract. The dried diethyl ether fraction was washed with hexane and the hexane insoluble extract was dissolved with the acetone followed by chloroform. The insoluble content of both the solvents were removed and the soluble fraction of chloroform was completely dried and the same was dissolved in dichloromethane. The solvent was removed under reduced pressure which afforded compound $\mathbf{1}(175 \mathrm{mg})$.

\section{DPPH Radical Scavenging Assay}

The radical scavenging activity of OA was measured using the DPPH method (Ghafoor, 2014). In brief, $1 \mathrm{~mL}$ solution of antioxidants $(0.5 \mathrm{mg} / \mathrm{mL}$ DMSO $)$ was mixed with $2 \mathrm{~mL}$ of $10 \mathrm{mg} / \mathrm{L}$ methanolic solution of DPPH. This solution was then mixed thoroughly and kept at an ambient temperature for $5 \mathrm{~min}$ followed by absorbance measurement at $517 \mathrm{~nm}$. The control solution for this test was made by mixing the reagent solution with methanol which did not contain sample or standard. The radical scavenging activity (RSA) was obtained using the following formula:

$$
\operatorname{RSA}(\%)=\frac{\text { Control OD }- \text { Sample OD }}{\text { Control OD }} \times 100
$$

\section{Cell proliferation assay}

HCT-116 cells were procured from the National Centre for Cell Science, Pune, India. The cells were cultured in Dulbecco's modified eagle's medium (DMEM) supplemented with $10 \%$ heat-inactivated Foetal bovine serum (FBS), penicillin (10 U/mL), streptomycin $(10 \mu \mathrm{g} / \mathrm{mL})$ and $0.2 \mathrm{mM}$ sodium pyruvate. The cultures were incubated in the presence of $5 \% \mathrm{CO}_{2}$ at $37{ }^{\circ} \mathrm{C}$ in humidified atmosphere. HCT-116 cells were seeded in 96-well micro plates at a density of $1 \times 10^{3}$ cells/well and incubated overnight. The medium was replaced with serum free DMEM supplemented with oleanolic acid at different concentrations (5-1000 $\mu \mathrm{g} / \mathrm{mL})$. After $48 \mathrm{~h}$ of incubation, the cell viability was determined using the colorimetric MTT assay as described earlier (Encalada et al., 2011). $15 \mu \mathrm{L}$ of MTT solution (stock $5 \mathrm{mg} / \mathrm{mL}$ ) was added to each well and subsequently incubated for $4 \mathrm{~h}$. The formazan crystals were dissolved using DMSO and absorbance was recorded at $570 \mathrm{~nm}$. The untreated cells (vehicle alone) were chosen as the negative control. Three independent assays were performed and the \% cell viability was calculated.

All experiments were carried out in triplicates and expressed as Mean $\pm \mathrm{SD}$. The statistical analysis for each experiment was done by using the one-way ANOVA at significance level $<0.05$.

\section{RESULTS AND DISCUSSION}

The methanolic extract of the black raisins was used for the isolation of OA. The methanolic extract was partitioned with water and ethyl acetate to obtain two distinct fractions. The ethyl acetate fraction was subjected to various solvent-solvent fractionation (Figure 1). Without using any chromatographic technique, compound $\mathbf{1}$ was isolated and the yield $(8.7 \mathrm{mg} / \mathrm{g})$ was obtained. The yield was significantly high when compared to other optimized methods (Ghafoor, 2014).

Compound (1): White powder with slight green pigmentation; $\mathrm{mp} 302-305^{\circ} \mathrm{C}$; $\mathrm{UV}(\mathrm{MeOH}) \lambda_{\max }(\log \epsilon)$ $235,282 \mathrm{~nm}$; IR (KBr) $v_{\max } 3446(\mathrm{OH}), 2926,2852,1687$, 1641, 1452, 1388, 1271, 1178, 1083,1035, $997 \mathrm{~cm}^{1}$; HREIMS $m / z 456.7032$ (calculated for $\mathrm{C}_{30} \mathrm{H}_{49} \mathrm{O}_{3}, \mathrm{~m} / \mathrm{z}$ 342.348); ${ }^{1} \mathrm{H} \mathrm{NMR}\left(\mathrm{CDCl}_{3}\right) \delta 5,27(1 \mathrm{H}, \mathrm{t}, \mathrm{H}-12), \delta 3.18$ $(1 \mathrm{H}, \mathrm{dd}, J=11.0,5.0 \mathrm{~Hz}, \mathrm{H}-3), \delta 2.85(1 \mathrm{H}, \mathrm{dd}, J=4.0$, $14.0 \mathrm{~Hz}, \mathrm{H}-18), \delta 0.93(3 \mathrm{H}, \mathrm{s}), \delta 0.839(3 \mathrm{H}, \mathrm{s}), \delta 0.963$ $(3 \mathrm{H}, \mathrm{s}), \delta 0.80(3 \mathrm{H}, \mathrm{s}), \delta 0.996(3 \mathrm{H}, \mathrm{s}), \delta 1.08(3 \mathrm{H}, \mathrm{s})$, $\delta 0.964(3 \mathrm{H}, \mathrm{s}) ;{ }^{13} \mathrm{C}$ NMR $\delta 39.16(\mathrm{C}-1), \delta 27.44(\mathrm{C}-2)$, $\delta 78.31(\mathrm{C}-3), \delta 38.43(\mathrm{C}-4), \delta 55.36(\mathrm{C}-5), \delta 18.1$ (C-6), $\delta 33.5(\mathrm{C}-7), \delta 46.23$ (C-8), $\delta 48.11$ (C-9), $\delta 36.77$ (C-10), $\delta 23.12(\mathrm{C}-11), \delta 122.25$ (C-12), $\delta 143.79(\mathrm{C}-13), \delta 41.49$ (C-14), $\delta 26.47$ (C-15), $\delta 22.66$ (C-16), $\delta 45.85$ (C-17), $\delta 32.16(\mathrm{C}-18), \delta 41.33$ (C-19), $\delta 30.20$ (C-20), $\delta 32.41$ (C-21), $\delta 22.57$ (C-22), $\delta 28.79$ (C-23), $\delta 14.9$ (C-24), $\delta$ $14.48(\mathrm{C}-25), \delta 16.32$ (C-26), $\delta 25.0(\mathrm{C}-27), \delta 180.4(\mathrm{C}-$ $28), \delta 32.62(\mathrm{C}-29)$ and $\delta 27.34(\mathrm{C}-30)$. The FT-IR data 


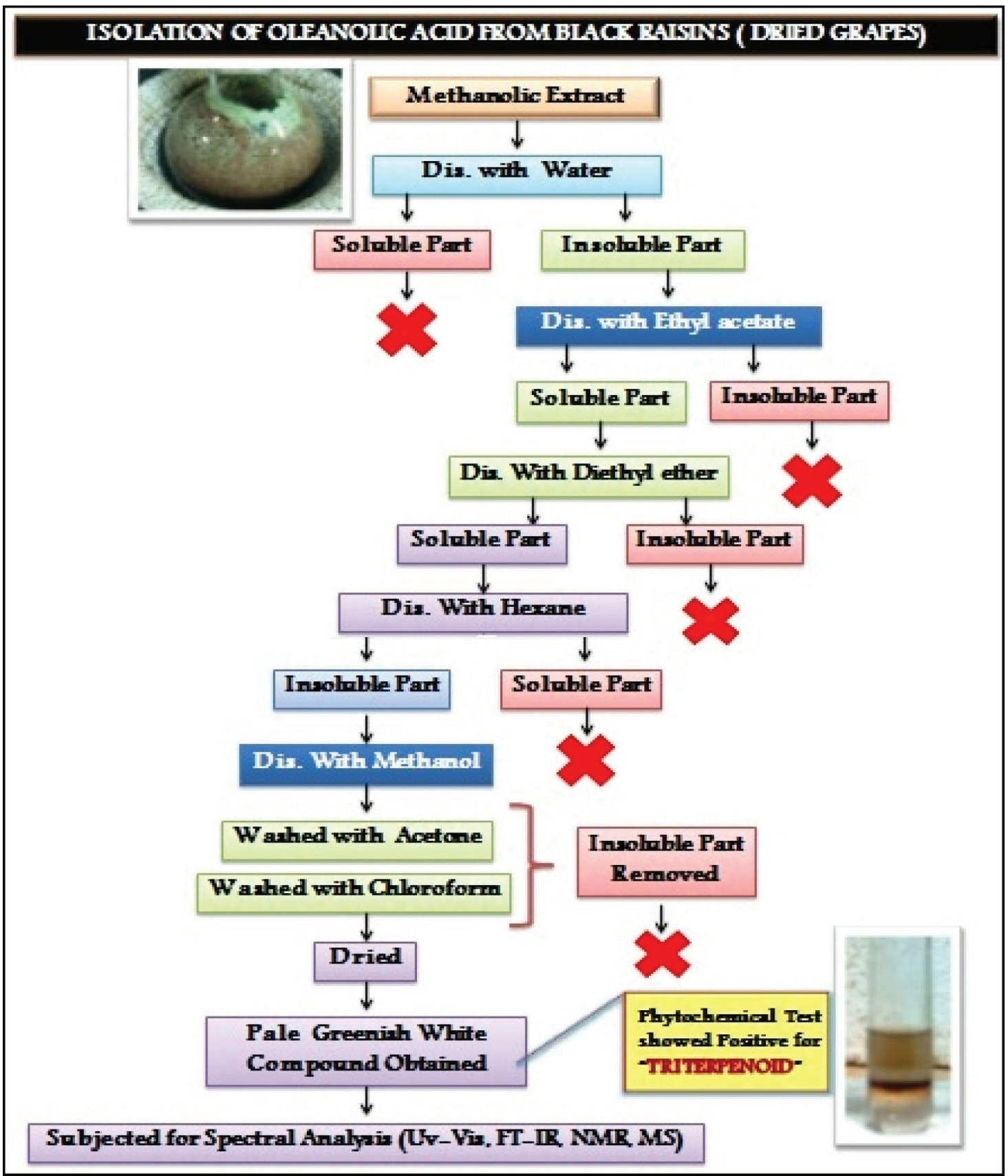

FIGURE 1 - Flow chart of isolation of oleanolic acid from the black raisins.

(Onoja, Ndukwe, 2013) and NMR data of 1 were identical to the published data of 3- $\beta$-Hydroxyolean-12-en-18 $\alpha$ 28-oic acid (18 - Oleanolic acid) (Seebachar et al., 2003; Zhang et al., 2004; Gohari et al., 2009; Maillard, Adewunmi, Hostettmann, 1992).

\section{Structural elucidation of compound (1)}

The Infrared (IR) analysis of compound 1 showed a peak at $3446 \mathrm{~cm}^{-1}$, which suggests the presence of a hydroxyl group, while the peak at $1687 \mathrm{~cm}^{-1}$ indicates the presence of a carbonyl group. These two peaks may be due to the presence of carboxylic acid functional group $(\mathrm{COOH})$. The peak at $1388 \mathrm{~cm}^{-1}$ may be due to the presence of tri-substituted olefinic group, while the peak at $1462 \mathrm{~cm}^{-1}$ may represent the presence of $-\mathrm{CH}_{3}$ and $-\mathrm{CH}_{2}$ - signals. The peak at $2926 \mathrm{~cm}^{-1}$ showed the presence of $\mathrm{C}-\mathrm{H}$ stretch for alkanes. This signal suggests that the molecule may be highly saturated. The molecular ion peak was established by HRMS spectrum which showed a molecular ion peak at $\mathrm{m} / \mathrm{z} 456.7032$, corresponding to the molecular formula $\mathrm{C}_{30} \mathrm{H}_{48} \mathrm{O}_{3}$ (calcd. 456.3603). 
In the HRMS, the pronounced peak at $\mathrm{m} / \mathrm{z} 418.9207$ represents the loss of $38 \mathrm{~m}$. u. corresponding to the $\mathrm{COOH}$ group. The prominent baseline peak at $\mathrm{m} / \mathrm{z} 248.6462$ represents a typical RDA fragmentation characteristic of $\Delta^{12}$-oleanane type triterpenes with $\mathrm{COOH}$ group, at C-17 (Ayatollahi et al., 2011). Another baseline peak at $\mathrm{m} / \mathrm{z}$ 203.6032 can be attributes to the loss of $\mathrm{COOH}$ from the fragment at $\mathrm{m} / \mathrm{z} 248$. The ${ }^{1} \mathrm{H}-\mathrm{NMR}$ spectrum of compound 1 shows seven singlets methyl groups at $\delta_{\mathrm{H}} 1.08,0.83,0.99$, $0.80,0.96,0.96$ and $0.93(\mathrm{H}-23,24,25,26,27,29$ and 30$)$. The carbonyl proton at C-3 position resonated at $\delta 3.18$ $(J=11.0,5.0 \mathrm{~Hz}$,) suggesting its $\alpha$ - and axial configuration and the olefinic proton at $\mathrm{C}-12$ appeared at $\delta 5.27$ as a triplet $(\mathrm{J}=3.5 \mathrm{~Hz})$. A one proton double doublet at $\delta 2.85$ was assigned to $\mathrm{H}-18$ on the basis of its chemical shift as well as the multiplicity pattern reported for $\mathrm{H}-18$ with $\beta$-stereochemistry. The ${ }^{13} \mathrm{C}$-NMR spectrum of compound 1 exhibited thirty carbon peaks. The peak at $\delta 180.4$ may be due to the presence of the carbonyl group assigned to $\mathrm{C}-28$. The two peaks at $\delta 122.25$ and $\delta-143.79$ may be due to the presence of a pair of sp2 hybridized carbon- carbon atoms assigned to $\mathrm{C}-12$ and $\mathrm{C}-13$. While the seven peaks at $\delta 28.79, \delta 14.9, \delta 14.48, \delta 16.32, \delta 25.0, \delta 180.4, \delta 32.62$ and $\delta 27.34$ can be attributed to the seven methyl groups which are assigned to C-23, C-24, C-25, C-26, C-27, C-29 and $\mathrm{C}-30$ respectively. Therefore compound 1 could be assigned as 3- $\beta$-Hydroxyolean-12-en-18 $\alpha$-28-oic acid $(18 \alpha-$ Oleanolic acid) (Figure 2).

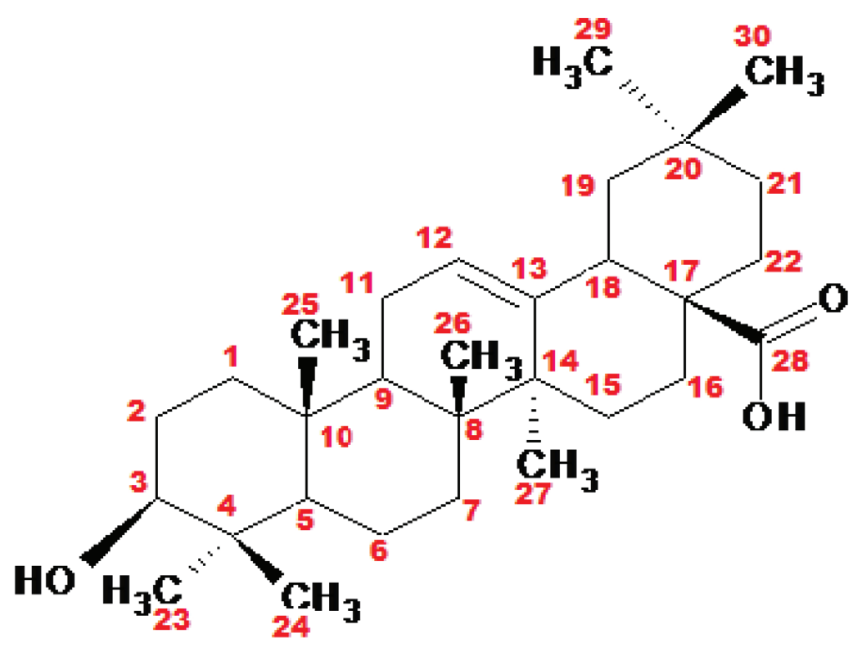

FIGURE 2 - Structure of compound $\mathbf{1}$ is oleanolic acid (OA).

\section{Free radical scavenging assay}

The free radical scavenging activity of oleanolic acid was investigated by DPPH assays and the result exhibited a good free radical inhibited activity when compared to standard antioxidants ascorbic acid (AA), gallic acid
(GA), pyrogallol (PG) and butylated hydroxytoluene (BHT). DPPH involves hydrogen atoms transfer and electrons transfer (Kaviarasan et al., 2007). The result of the present investigation illustrated that oleanolic acid may reduce/inhibit the production of free radicals by donating hydrogen molecules and result in the decolourization in the DPPH assays. Figure 3 demonstrates the abilities of the different antioxidants to scavenge free DPPH radicals. It is evident that oleanolic acid has $88.30 \pm 1.84 \%$ DPPHscavenging activity, which is comparable with that of AA (93.11 $\pm 2.14 \%)$, GA $(90.85 \pm 1.32 \%)$, PG $(93.03 \pm 1.12 \%)$ and BHT $(93.20 \pm 2.33 \%)$. The minimum inhibitory concentration $\left(\mathrm{IC}_{50}\right)$ of oleanolic acid was found to be $61.5 \mu \mathrm{g} / \mathrm{mL}$.

\section{Anti-proliferative assay}

The anti-cancer efficacy of OA was determined using cell-based in vitro techniques. The proliferation of HCT116 was found to be inhibited which was evident from reduced cell viability of OA treated HCT-116 cells when compared with the untreated control cells. This inhibitory effect was concentration dependent and was found to lower the cell viability at the concentration $50 \mu \mathrm{g} / \mathrm{mL}$ of OA. The required concentration for the $50 \%$ inhibition $\left(\mathrm{IC}_{50}\right)$ of cells was $40 \mu \mathrm{g} / \mathrm{mL}$ (Figure 4 ). The similar class of pentacyclic triterpenoids like Asiatic acid (AA), betulinic acid (Bet A), boswellic acid (BA), glycyrrhizin, lupeol, ursolic acid (UA) and their derivatives were also reported previously to have a potent anticancer effect (Paduch, KandeferSzerszen, 2014). Asiatic acid (AA) caused about a 50\% reduction in the viability of ovarian cancer cells SKOV3 and OVCAR-3 at the concentration of $40 \mu \mathrm{g} / \mathrm{mL}$ (Ren et al., 2016). Betulinic acid was active against breast cancer cell lines with an $\mathrm{IC}_{50}$ value on MDA-MB-231 $(21.9 \mu \mathrm{M})$ and MDA-MB-468 (46.0 $\mu \mathrm{M})$ cell lines (Weber et al., 2014). It also showed concentration-dependent anti-proliferative activity on paclitaxel-resistant lung $\mathrm{H} 460$ cells and $\mathrm{IC}_{50}$ was found to be $50 \mu \mathrm{M}$ (Zhan et al., 2018). Glycyrrhizin exhibited a significant inhibition at $100 \mu \mathrm{M}$ on the human lung carcinoma cell line, HCC 827 cells after $48 \mathrm{~h}$ (Ma et al., 2016) but the cell viability was not affected on the primary mouse mammary epithelial cells at 50,100 and $200 \mu \mathrm{g} /$ $\mathrm{mL}$ (Fu et al., 2014).Lupeol also inhibited the growth of the MCF-7 breast cancer cells with a dose-dependent increase providing an $\mathrm{IC}_{50}$ value of the compound as $80 \mu \mathrm{M}$ (Pitchai, Roy, Ignatius, 2014). Oleanolic acid from Coleus tuberosus, has an antiproliferative activity through induced apoptosis in the MCF-7 cells and was in a dose-dependent manner. IC50 of OA was found at $48.61 \mu \mathrm{g} / \mathrm{mL}$ after $48 \mathrm{~h}$ (Nugraheni et al., 2011). Colon carcinoma HCT15 cells 


\section{DPPH Radical Scavenging Activity}

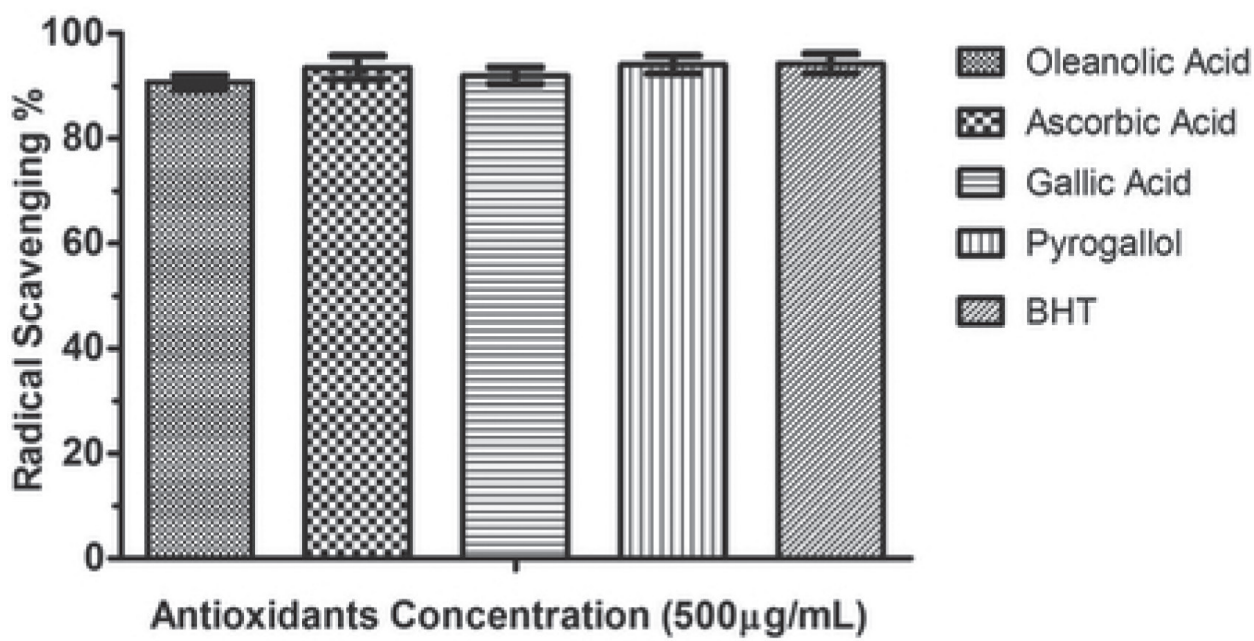

FIGURE 3 - Antioxidant activity (DPPH method) of oleanolic acid.

were treated with various concentrations of ursolic acid (UA) and OA for $48 \mathrm{~h}$. The cell viability was significantly decreased in a dose-dependent manner and $\mathrm{IC}_{50}$ of UA and OA was found to be $30 \mu \mathrm{M} / \mathrm{L}$ and $60 \mu \mathrm{M} / \mathrm{L}$ respectively (Li, Gai, Yang, 2002). OA administered in a dose and timedependent manner exhibits a significant decrease in the cell viability of GBC-SD and NOZ (human gallbladder cancer) cell lines. The $\mathrm{IC}_{50}$ of the GBC-SD and NOZ cells was found to be $50 \mu \mathrm{M} / \mathrm{L}$ at $48 \mathrm{hr}$ (Li et al., 2015). The previous report found that $\mathrm{OA}$ has similar $\mathrm{IC}_{50}$ of $47 \mu \mathrm{g} / \mathrm{mL}$ against the same cell line HCT 116 (Abdelwahab, Hussein, Kadry, 2015). According to morphological changes in
HCT116 cells, OA has a direct cytotoxic effect which is concurrent with a previous study on it and it has been reported that OA has a cytotoxic activity in HCT15 (Li, Gai, Yang, 2002). Some studies have also supported that oleanane-type triterpenoids had inhibitory effects on DNA polymerase beta and DNA topoisomerases (Wada, Iida, Tanaka, 2001).

\section{CONCLUSION}

OA obtained from $V$. vinifera can be established as a suitable drug candidate for anti-colon cancer from

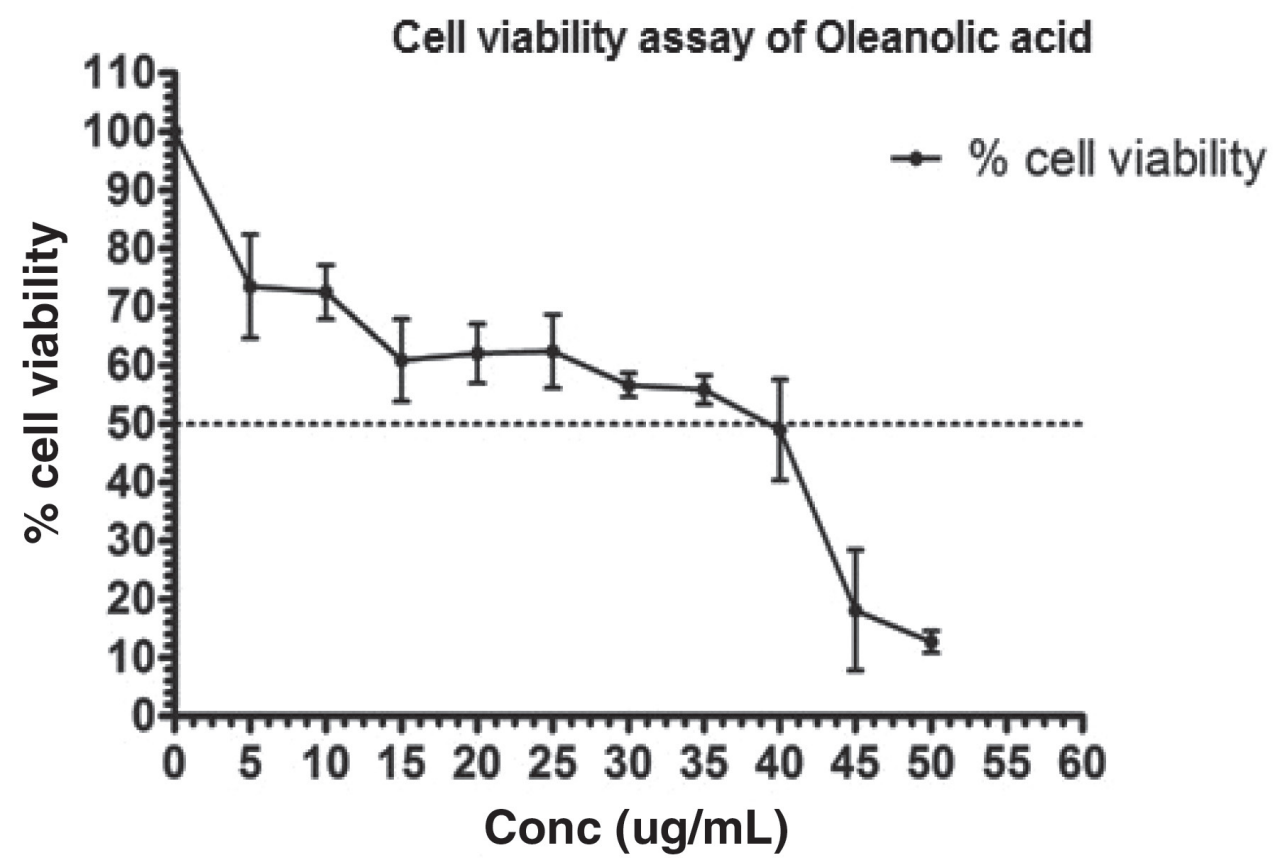

FIGURE 4 - Anti-proliferative efficacy of oleanolic acid against HCT116 colon cancer cells. 
based on the inferences drawn from the antioxidant and cytotoxic assays. These findings of the present study show black raisin as a hopeful source to inhibit colorectal cancer. Though OA metabolites are present in low quantity in raisins they possess good anticancer activity due to the synergetic effect of the various metabolites that are present in the black raisins. Further refinements may attribute to elucidate the molecular mechanism of interaction for anti-colon cancer activity of OA. Considering the clinical efficacy and toxicity of numerous anticancer agents which are unknown and uncertain, understanding the fundamental role of herbal extracts has been found to play an essential role in the development of herbal drugs and its use in the treatment of cancer.

Supplementary data: UV- Vis spectra, FT-IR spectra, NMR spectra ( ${ }^{1} \mathrm{H}$ and ${ }^{13} \mathrm{C}$ NMR) and HR-ESI-MS spectra for the compound $\mathbf{1}$ (oleanolic acid).

\section{ACKNOWLEDGEMENT}

The authors are grateful to the management of VIT University for their support in pursuing research and to the Sophisticated Analytical Instrument Facility, Indian Institute of Madras for MS and NMR spectral analysis.

\section{REFERENCES}

Abdelwahab MF, Hussein MH, Kadry HH. Cytotoxicity and antioxidant activity of new biologically active constituents from Micromeria nervosa grown in Egypt. Bull Fac Pharm Cairo Univ. 2015;53(2):185-194.

Allouche Y, Jimenez A, Uceda M, Aguilera MP, Gaforio JJ, Beltran G. Triterpenic content and chemometric analysis of virgin olive oils from forty olive cultivars. J AgricFoodChem.2009;57(9):3604-3610.

Alvarez ME, Maria AO, Saad JR. Diuretic activity of Fabiana patagonica in rats. Phytother Res. 2002;16(1):71-73.

Ayatollahi AM, Ghanadian M, Afsharypour S, Abdella OM, Mirzai M, Askari G. Pentacyclic triterpenes in Euphorbia microsciadia with their T-cell proliferation activity.Iran J Pharm Res. 2011;10(2):287-294.

Encalada MA, Hoyos KM, Rehecho S, Berasategi I, Ciriano MGID, Ansorena D, et al. Antiproliferative effect of Melissa officinalis on human colon cancer cell line. Plant Foods Hum Nutr.2011;66(4):328-334.
Fu Y, Zhou E, Wei Z, Liang D, Wang W, Wang T, Guo M, Zhang $\mathrm{N}$, Yang Z. Glycyrrhizin inhibits the inflammatory response in mouse mammary epithelial cells and a mouse mastitis model. FEBS J. 2014;281(11):2543-57.

Ghafoor K. Antioxidant properties of oleanolic acid from grape peel. Agro Food Ind Hi-Tech. 2014;25(2):54-57.

Gohari AR, Saeidnia S, Hadjiakhoondi A, Abdoullahi M, Nezafati M.Isolation and quantificative analysis of oleanolic acid from Satureja mutica Fisch.\& C.A. Mey. J Med Plants. 2009;8(5):65-69.

Kashiwada Y, Nagao T, Hashimoto A, Ikeshiro Y, Okabe H, Cosentin LM, et al. Anti-HIV activity of 3-O-acyl ursolic acid derivatives. J Nat Prod. 2000;63(12):1619-1622.

Kaviarasan S, Naik GH, Gangabhagirathi R, Anuradha CV, Priyadarsini KI.In vitro studies on anti-radical and antioxidant activities of fenugreek (Trigonella foenumgraecum) seeds. Food Chem. 2007;103(1):31-37.

Li J, Gai WJ, Yang QY. Effects of urosolic acid and oleanolic acid on human colon carcinoma cell lines HCT15. World J Gasteroenterol. 2002;8(3):493-495.

Li HF, Wang XA,Xiang SS,Hu YP, Jiang L,Shu YJ,Li ML, Wu XS, Zhang F, Ye YY, Weng H,Bao RF, Cao Y,Lu W,Dong Q, Liu YB. Oleanolic acid induces mitochondrial-dependent apoptosis and G0/G1 phase arrest in gallbladder cancer cells. Drug Des Devel Ther. 2015;9:3017-3030.

Ma YF, Guo NN, Chu J, Jin S, Yang B, Li J, Zhang T, Guo JT, Chen L, Liang CY, Wang LH, Liu Y. Glycyrrhizin treatment inhibits proliferation and invasive potential of lung cancer cells. Int J Clin Exp Med. 2016;9(6):10592-10596.

Maillard M, Adewunmi CO, Hostettmann KA. Triterpene glycoside from the fruits of Tetrapleura tetraptera. Phytochem, 1992;31(4):1321-1323.

Nugraheni M, Santoso U, Suparmo H, Wuryastuti H. In vitro antioxidant, antiproliferative and apoptosis effect of Coleus tuberosus L. Afr J Food Sci. 2011;5(4):232-241.

Onoja E, Ndukwe IG. Isolation of oleanolic acid from chloroform extract of Borreri astachydea (DC) Hutch. J Nat Prod Plant Resour. 2013;3(2):57-60. 
Paduch R, Kandefer-Szerszeń M. Antitumor and antiviral activity of pentacyclic triterpenes. Mini-Rev Org Chem.2014;11(3):262268.

Patlolla JM, Rao CV. Triterpenoids for cancer prevention and treatment: Current status and future prospects. Curr Pharm Biotechnol. 2012;13(1):147-155.

Pensec F, Paczkowski C, Grabarczyk M, Wozniak A, Gellon $\mathrm{MB}$, Bertsch $\mathrm{C}$, et al. Changes in the triterpenoid content of cuticular waxes during fruit ripening of eight grape (Vitis vinifera) cultivars grown in the upper Rhine valley. J Agric Food Chem. 2014;62(32):7998-8007.

Pitchai D, Roy A, Ignatius C. In vitro evaluation of anticancer potentials of lupeol isolated from Elephantopus scaber L. on MCF-7 cell line. J Adv Pharm Technol Res. 2014;5(4):179-84.

Prasad S, Tyagi AK. Traditional medicine: The Goldmine for modern drugs. Adv Tech Biol Med. 2015;3:1-2.

Sasikumar K, Ghosh AR. Isolation of myristyl alcohol from Hybanthus enneaspermus. Bangladesh J Pharmacol. 2017;12(2):113-14.

Seebacher W, Simic N, Weis R, Saf R, Kunert O. Complete assignments of ${ }^{1} \mathrm{H}$ and ${ }^{13} \mathrm{C}$ NMR resonance of oleanolic acid, $18 \alpha$-oleanolic acid, ursolic acid and 11-oxo derivatives. Magn Reson Chem. 2003;41(8):636-638.

Shoba S, Sasikumar K, Sathiavelu M. Isolation of isosativenetriol from endophytic fungus Cochliobolus spp. of Aerva lanata. Bangladesh J Pharmacol. 2018;13(1):57-58.

Singh GB, Singh S, Bani S, Gupta BD, Banerjee SK. Antiinflammatory activity of oleanolic acid in rats and mice. J Pharm Pharmacol. 1992;44(5):456-8.
Ren L, Cao QX, Zhai FR, Yang SQ, Zhang HX. Asiatic acid exerts anticancer potential in human ovarian cancer cells via suppression of PI3K/Akt/mTOR signaling. Pharm Biol. 2016;54(11):2377-2382.

Tang HQ, Hu J, Yang L, Tan RX. Terpenoids and flavonoids from Artemisia species. Planta Med. 2000;66(4):391-393.

Wada S, Iida A, Tanaka R. Screening of triterpenoids isolated from Phyllanthus flexuosus for DNA topoisomerase inhibitory activity. J Nat Prod.2001;64(12):1545-1547.

Wang L, Waltenberger B, Wenzig EMP, Blunder M, Liu X, Malainer $\mathrm{C}$, et al. Natural product agonists of peroxisome proliferators activated receptor gamma (PPARg): a review. Biochem Pharmacol. 2014;92(1):73-89.

Weber D, Zhang M, Zhuang P, Zhang Y, Wheat J, Currie G, AlEisawi $Z$. The efficacy of betulinic acid in triple-negative breast cancer. SAGE Open Med.

2014;2:2050312114551974.

Xia EQ, Deng GF, Guo YI, Li HB. Biological activities of polyphenols from grapes. Int J. Mol Sci. 2010;11(2):622-646.

Zhan XK, Li JL, Zhang S, Xing PY, Xia MF. Betulinic acid exerts potent antitumor effects on paclitaxel-resistant human lung carcinoma cells (H460) via G2/M phase cell cycle arrest and induction of mitochondrial apoptosis. Oncol Lett. 2018;16(3):3628-3634.

Zhang Y, Jayaprakasam B, Seeram NP, Olson LK, Witt DD, Nair MG. Insulin secretion and cyclooxygenase enzyme inhibition by cabernet sauvignon grape skin compounds. J Agric Food Chem. 2004;52(2):228-233.

Received for publication on $07^{\text {th }}$ April 2017 Accepted for publication on $17^{\text {th }}$ December 2018 